\title{
Success of Various Satyagharas in Dhamtari Area (A Study From 1920-1930).
}

\author{
Vipin Tirkey \\ Assistant Professor, History, Guru Ghasidas Vishwavidyalaya, Bilaspur, C.G.
}

\begin{abstract}
In the Gandhian era, one of the famous movements called as Non-Cooperation Movement; which was started by Gandhiji in 1920 against the British Govt. As soon as in the month of May, Mill Labors Satyagraha came to an end in Rajnandgaon, a few months later in July "Nahar Satyagraha" started at Kandel village of Dhamtari tahsil in 1920. This was the First Satyagraha in the National Freedom Movement of India.Kandel is the name of village in Dhamtari tahsil. ${ }^{3}$ At the Mahanadi shore there are two places called Rudri and Madamsilli, where the dam construction was done for irrigation purpose in those areas by the British Govt. By giving water to peasants Govt. used to collect irrigation tax. The villagers did not want to pay the tax.Gattasilli Satyagraha got over successfully, in the same year on $22^{\text {nd }}$ August 1930, a group of Satyagrahis decided to cut reserved grass of the Forest Department in Nawagaon and thus, by doing this broke the law.
\end{abstract}

\section{Introduction:}

Once upon a time Gandhiji had said that Govt. of English is a Saitan Govt., she had no sadness on her blunder mistakes. Thus, in order to achieve Swaraj we have to apply the policy of Non-Cooperation and that should be non-violence. Before 1915 Gandhiji got success in all the various movements which was held against the English Govt. in South Africa and then in the same year after coming to India got success in Champaran, Kheda as well in Ahmadabad. Here, Gandhiji got help from all Indians. In 1915, Shri Gopal Krishna Gokhale died and Bal Gangadhar was sick, in this critical situation Gandhiji came forward as a chief leader and decided to lead the Indian political. At the very beginning Gandhiji was in favor of British Govt.; but after the incidents of 1919 Rowlett Act, Jallianwala Bagh Massacre and khilafat question made Gandhiji to rethink about the nation thus, later on Gandhiji became one of the main protesters of British Govt. Thus, in 1920, Congress gave authority to Gandhiji in order to start Non-Cooperation Movement against the Govt. Finally, by returning title "Kaiser-e-Hind", Gandhiji inaugurated the Non-Cooperation Movement. This was a nationwide movement, thus it affected Chhattisgarh especially in Dhamtari tahsil like the other parts of India. As soon as the NonCooperation Movement started, its impact was seen in Dhamtari tahsil; people were so happy of this region to take part in the movement against British Govt.

There were various programmes of the movement, as following:

- Resign from govt. posts. And titles should be returned.

- All official functions, durbars, felicitation functions should be boycotted by teachers and students.

- Govt. institutions of learning should be boycotted by teachers and students.

- Lawyers should boycott the courts.

- The individual seeking elections should withdraw their nomination.

- Foreign goods should be boycotted.

- No tax campaign should be organized.

- Export of foreign goods should be stopped.

- Handicrafts and weaving should be encouraged.

\section{Kandel Nahar Satyagraha 1920}

As soon as in time month of May, Mill Labors Satyagraha came to an end in Rajnandgaon, then few months later in July "Nahar Satyagraha" started at Kandel village of Dhamtari tahsil in 1920. This was the First Satyagraha in the National Freedom Movement of India. Pt. Sundarlal Sharma, Narayan Rao Medhawale and Babu Chotelal Srivastava were the chief leaders of the Satyagraha. ${ }^{1}$ In the second decade of $20^{\text {th }}$ Century, Dhamtari tahsil belonged to Raipur district. From this tahsil onwards began the Kandel Movement, i.e. the Movement is called as Kandel Nahar Satyagraha. ${ }^{2}$ Kandel Satyagraha was one of the famous and successful movement in India. The Satyagraha was led by Pt. Sundarlal Sharma and other leaders of this area. During the Kandel Satyagraha only, Gandhiji's first arrival took place in Chhattisgarh in 1920.

Kandel is the name of village in Dhamtari tahsil. ${ }^{3}$ At the Mahanadi shore there are two places called Rudri and Madamsilli, where the dam construction was done for irrigation purpose in those areas by the British 
Govt. By giving water to peasants Govt. used to collect irrigation tax. Regarding the water facility there had been done ten years settlement in between villagers and Govt.; on the other hand irrigation tax was too high for villagers. They had not that much capacity to pay for it. Because of this reason only, department of irrigation according to its settlement plan decided to bring many villagers under govt. Thus, without demanding water from villagers' order to bring Kandel village under their settlement, govt. flew some water in their fields. Thus, British Govt. forcefully declared money payment warrant about 4033/- rupees from Kandel villagers. In protest of this villagers started Satyagraha against Govt. On the other hand British Govt. blamed to villagers and illegally started to collect money. Finally all the people of this village protested the brutal policy of Govt.

In order to ponder upon this matter all the chief leaders of Dhamtari tahsil had an assembly. In this assembly Pt. Sundarlal Sharma, Narayan Rao Medhawale, Babu Chotelal Srivastava took part. ${ }^{4}$ Some decisions were made in the assembly that to start Satyagraha against torture of British Govt. and not to pay warrant money. Because of this action Govt. started suppressing the villagers and thus, their cattle were taken by the Govt. but there was nobody, who could buy all these cattle. At this time people of these areas became aware about their rights and they awoke by the Satyagraha of Gandhiji. Thus, people's main aim was to protest British Govt. In protest of the Govt. many people were arrested and were tortured by the Govt. The Kandel Satyagraha went on for months and months. Day by day torture of Govt., was increasing. Therefore, in this pathetic situation chief leaders of these areas decided to handover the movement to Gandhiji. Thus, leaders prayed to Gandhiji and Gandhiji accepted it with whole heartedly. Later on Pt. Sundarlal Sharma went to meet Gandhiji in Calcutta. ${ }^{5}$ On the other hand Govt. got all the information regarding the Satyagraha and became more consciousness about it. In order to know the fact Deputy-Commissioner of Raipur went to the movement place and investigated the reality. His final suggestion was in favor of the Kandel villagers, and also DeputyCommissioner of Raipur declared the cancellation of fined amount as well their cattle were returned. As a consequent, before arrival of Gandhiji to Chhattisgarh, the Kandel Nahar Satyagraha ended up successful in favor of villagers. Thus, it was the first successful Satyagraha in Dhamtari tahsil of Raipur district in Chhattisgarh.

In connection to the Kandel Nahar Satyagraha Gandhiji arrived to Chhattisgarh in the month of Dec.in 1920. ${ }^{6}$ Thus, Gandhiji arrived first in Raipur, where he was welcomed by people of this area. Gandhiji addressed to all people from the chawk and there he said that in order to free from slavery, you have to join in the Non-Cooperation Movement. On 21 ${ }^{\text {st }}$ Dec. 1920 Gandhiji reached to Dhamtari. ${ }^{7}$ There Gandhiji was welcomed by people of Dhamtari and at Mandai-Band Chawk Gandhiji addressed to all people. A Jamindars of Dhamtari tahsil Bajirao Kridutt gave a bag of 501/- rupees to Gandhiji and welcomed him. Gandhiji in his speech congratulated to all people of Dhamtari tahsil for getting success in the Kandel Satyagraha; and also appealed to take part actively in the programme of Congress. At $3.00 \mathrm{pm}$ Gandhiji returned to Raipur from Dhamtari. On his way to Raipur Gandhiji met with the people of Kurud. After reaching to Raipur, Gandhiji addressed women in an assembly at Anand-Samaj-Vachnalaya. During this assembly only, all women donated around 2000/- rupees for the Tilak Swaraj Fund. After that Gandhiji went to Nagpur in order to attend the Congress session on $26^{\text {th }}$ Dec. 1920. However, first arrival of Gandhiji in 1920 to Chhattisgarh left a deep impact in the hearts and minds of all people in this region. Thus, all young fellow men and women were actively participated in the programme of Congress and played a notable role especially in the Freedom Movement of India. All people of this region contributed to make success the Non-Cooperation Movement.

In order to make Kandel Nahar Satyagraha successful, Pt. Sundarlal Sharma was supported by Nathuji Jagtap, Bhavani Prasad Mishra, Madhav Rao Sapre, Abdul Rauf, Hamid Ali, Vaman Rao Lakhe, Thakur Pyarelal Singh, Laxmi Narayan Das, Khubchand Baghel, Yatiyatan lal etc. and other Congress leaders as well the Mass. ${ }^{8}$

\section{Sihawa - Nagari Jungle Satyagraha 1922}

Sihawa - Nagari is a nagar in Dhamtari tahsil. In this place tribals are more in majority. ${ }^{9}$ Sihawa Nagari is fully surrounded by the forest and around $70 \%$ population resided are Adivasi. Here they broke the jungle law and started Satyagraha against the British Govt. ${ }^{10}$ Here, Adivasis were exploited too much by the Govt. and before starting the Satyagraha volunteers gave information to officers of the Forest Department. Because of the awakening of these tribes through the various programmes on movement, they too broke the forest laws and decided to start Jungle Satyagraha against the British Govt. As a result they entered into the reserved forest and started taking wood. It was the movement against those officers, who always exploited them. On $21^{\text {st }}$ Jan. 1922 Sihawa - Nagari Jungle Satyagraha was started. ${ }^{11}$ As soon as British Govt. officers got information about it, few days later starting of the movement; one battalion of police force under British police officer reached to Nagari and they started torturing villagers. On the other hand court gave decision against villagers that they have been stolen wood from the reserved forest area. All the Satyagrahis were falsely accused for it. But all Satyagrahis without fearing from British Govt. declared it was the right moment. However, many Satyagrahis were beaten up and got severe torture even ladies were also suffered a lot. There were some people 
like Vishambhar Patel, Pancham Singh,and Harakram Som who were punished. On third day of the Satyagraha, an English officer, police captain, Raipur circle inspector, sub inspector, and many police constables went to Nagari from Dhamtari tahsil in order to suppress down. ${ }^{12}$ As a result of the Satyaghara, around 33 Satyagarhis were got for 3-3 months jail and 6 Satyagrahis got for 5 months jail with fine. According to Dr. Ramgopal Sharma. "A Adivasi called Nathunram was put into Sihawa jail for 4 days in connection to this. As well in the jail he was beaten with stick 25 times. At last Forest Department stopped exploiting Adivasis. ${ }^{13}$

In 1921, there was Congress session was held in Ahmadabad. From this region many leaders went to participate in the session. After returning from Ahmadabad, chief leaders of these areas such as Pt. Sundarlal Sharma, Narayan Rao Medhawale etc. went to Sihawa - Nagari. All these leaders motivated to Satyagrahis that to stop Satyagraha with the permission of the Province Congress Committee. On the other hand they protested against British Govt. Thus, in the Sihawa - Nagari, there was the peaceful atmosphere. British Govt. stopped torturing of all labors. Thus, all the Satyagrahis were welcomed by these entire region's people.

Because of the Non-Cooperation Movement when it was becoming too much violence, finally, its result was seen on $5^{\text {th }}$ February 1922, on this day Chauri - Chaura incident took place in Gorakhpur district in U. P. In this event one police officer along with 21 constables were burnt alive in the jail by the Mass. Thus, Gandhiji as the chief leader of the Movement decided to call off it. In Bardoli Congress meeting, it was sad event for Gandhiji and for the Nation that people was becoming too violent in various parts of the Nation.

\section{Gattasilli Jungle Satyagraha 1930}

The Satyagraha of Gattasilli sought too much the Govt. in Dhamtari tahsil. In this place since there are no Sea, thus, people of this village decided to start Jungle Satyagraha. Gattasilli is a village in Dhamtari tahsil in 1930; an incident took place in Gattasilli village. The incident was that around 500 animals were put into cattle house by the British Govt., because of pasturing in the reserved forest area. ${ }^{14}$ People of this village tried a lot to get back their animals but failed. As a result, Shri Narayan Rao Medhawale and Shri Nathuji Jagtap both went that place and started Satyagraha. Satyagrahis requested to British Govt. to leave their animals, but Govt. didn't listen to them. Thus, at last all people went at cattle house and slept in front of the door. They were forced to go from there but when they refused then hot water was thrown on them. But they didn't move from there at all. Satyagrahis were ready to accept all type of tortures. In the words of Dr. Ramgopal Sharma that in June 1930, from Temli village around 300 animals were put into the cattle house of Gattasilli by the Govt. officers of the Forest Department. The main reason behind it was grazing of animals in the reserved forest area of the Govt. ${ }^{15}$

Thus, the owners of animals were gone to the Congress Committee of Dhamtari. The committee promised to help them in this matter. After that they went to Gattasilli. On the other hand police officers got information of this; they took all animals for selling in the market. Finally, Govt. decided to leave their cattle and thus, it can be sad that this Satyagraha of Gattasilli got success in their motives during the Civil Disobedience Movement.

\section{Rudri Nawagaon Jungle Satyagraha 1930}

As soon as Gattasilli Satyagraha got over successfully, in the same year on $22^{\text {nd }}$ August 1930, a group of Satyagrahis decided to cut reserved grass of the Forest Department in Nawagaon and thus, by doing this broke the law. This Satyagraha was led under the leadership of Shri Narayan Rao Medhawale and Shri Jagtap, but both of them were arrested and in this region act 144 was applied by the Govt. ${ }^{16}$ According to Shobharam Dewangan that one of the another Jungle Satyagraha occurred in Dhamtari tahsil, around 3 miles far place called Nawagaon. A group of 5 volunteers in each group there were one chief volunteer and four villagers, by cutting grass they will break the jungle laws. Thus, they inaugurated the Satyagraha and it will be continued for 8 months. On $21^{\text {st }}$ August 1930, in a public assembly Satyagraha and its progrmmes were declared in Dhamtari. ${ }^{17}$ In the assembly, Jagtap was assigned to start Satyagraha peacefully, but he was arrested by the police. Before going to jail, Jagtap advised Babu Chotelal Srivastava to continue the Movement. When the Mass was moving forward, police sub - inspector of Dhamtari stopped them. Though there was a critical condition but Babu Chotalal Srivastava motivated the Mass to continue the Movement, finally all were arrested. Thus, the Satyagraha continued for days after days.

In connection to the Satyagraha, on $16^{\text {th }}$ September 1930 , at $2 \mathrm{pm}$ or $2.30 \mathrm{pm}$ an unpleasant incident took place, when police started lathi charge on the Mass. In the incident place Tahsildar S. V. Baret of Dhamtari was presented there. When Mass tried to escape police chased them, and because of heavy rain when sub inspector was following them suddenly fell down on the ground and got injury in his one eye; he was bleeding. By seeing this other police men and govt. officers who were presented there, thought that mass had stoned at sub - inspector. Thus, Govt. ordered for lathi charge and firing too. Because of firing Minduji Kumbhkar and Ratnuji from Lamkeni village got injuries. In the condition both were arrested and were sent to Raipur jail, in the jail Minduji Kumbhkar after 2 or 3 days died. ${ }^{18}$ In the month of Sept. a large crowd of people reached to Rudri and there police took such an action as lathi charge. Because of this action of police a no. of people got 
injury thus, people decided to broke the act of 144 and once again reached to Rudri. On the other hand Govt. distributed without signature pamphlet in the name of Dhamtari Congress Committee. Though chief leaders were arrested but the movement continued. In order to suppress the movement in September month, Govt. distributed pamphlet for the assembly. Thus, people breaking the act of 144 went to assemble at Nawagaon. As a result of this, police started lathi charge on the Mass. ${ }^{19}$ This time too police used more force against the crowd. During this moment one police constable got injury and on this basis police fired also. In the police firing one person named Sindhu Kumar died and many others got injured. Another person named Ralu died few days later of this incident because of getting severe injury.

This Satyagraha continued till $5^{\text {th }}$ March 1931, when Delhi Pact was held in between Gandhiji and Lord Irwin. As a result, after the Delhi Pact Gandhiji decided to call off the Civil Disobedience Movement. As a result of the Pact, in Raipur district also the Movement came to an end and after an agreement all prisoners were released from jail. After the Second Round Table Conference 1931, Gandhiji was arrested, but after releasing from the jail once again Gandhiji decided to restart the Civil Disobedience Movement on $1^{\text {st }}$ Jan. 1932. Thus, second phase of the Movement started from 1932 to 1934.

Thus, at the end it would be clear to say that as a prominent leader of the nation Gandhiji came forward in order to guide the Non-Cooperation Movement in 1920. Because of his guidance and inspiration, people of the nationwide actively participated in the movement, and directly or indirectly contributed for the nation. Like the other parts of the nation this movement affected especially Dhamtari tahsil of Raipur district. Finally, people of Dhamtari region also came forward and raised their voices against British government. Hence, in these regions, during Non-Cooperation Movement and Civil Disobedience Movement various satyagrahas occurred against the English government such as Kandel Nahar Satyagraha 1920, Sihawa-Nagari Jungle Satyagraha 1922, Gattasilli Jungle Satyagraha 1930 and Rudri Nawagaon Jungle Satyagraha in the same year 1930 under the guidance of great personalities of these areas. Some of the prominent leaders were Pt. Sundarlal Sharma, Babu Chotelal Srivastava, Narayan Rao Medhawale and Nathuji Jagtap all of them made a tremendous efforts for the development of national awakening among people of Dhamtari tahsil. Eventually, in all the satyagahas which took place at various times, got successful in favor of the people of this region.

\section{References:}

[1]. Dr. Arvind Sharma, Chhattisgarh Ka Rajnitik Itihas, Arpa ocket Books, Bilaspur, 1999, P.99.

[2]. Dr. Bhagwan Singh Verma, Chhattisgarh ka Itihas (Prarambh se 2000 ad), Madhya Pradesh Hindi Granth Akadami, Bhopal, 2007, P.222.

[3]. Ibid., P.222

[4]. Dr. Bhagwan Singh Verma, Chhattisgarh ka Itihas (Prarambh se $2000 \mathrm{ad})$, P.222

[5]. Ibid., P.222.

[6]. Ibid., P.223.

[7]. Dr. Bhagwan Singh Verma, Chhattisgarh ka Itihas (Prarambh se $2000 \mathrm{ad),} \mathrm{P.223.}$

[8]. Pt. Bhuvanlal Mishra, Pt. Sunderlal Sharma Shatabdi Jayanti Samaroh Patrika, Dammani Printing Press, Rajim, 1981, P.4.

[9]. Dr. Bhagwan Singh Verma, Chhattisgarh ka Itihas (Prarambh se 2000 ad), P.225.

[10]. Dr. Ramgopal Sharma, Dr, Taru Tiwari, Chhattisgarh ka Prashasan Evam Swatantra Sangram Andolan (1854-1947),Lokashar Prakashan, Bilaspur, P.35.

[11]. Dr. Bhagwan Singh Verma, Chhattisgarh ka Itihas (Prarambh se $2000 \mathrm{ad),} \mathrm{P.225.}$

[12]. Dr. Ramgopal Sharma, Dr, Taru Tiwari, Chhattisgarh ka Prashasan Evam Swatantra Sangram Andolan (1854-1947), P.36.

[13]. Ibid., P.36.

[14]. Dr. Bhagwan Singh Verma, Chhattisgarh ka Itihas (Prarambh se 2000 ad), P.229.

[15]. Dr. Ramgopal Sharma, Dr, Taru Tiwari, Chhattisgarh ka Prashasan Evam Swatantra Sangram Andolan (1854-1947), P.42.

[16]. Dr. Bhagwan Singh Verma, Chhattisgarh ka Itihas (Prarambh se 2000 ad), P.229.

[17]. 17.Dr. Ramgopal Sharma, Dr, Taru Tiwari, Chhattisgarh ka Prashasan Evam Swatantra Sangram Andolan (1854-1947), P.42.

[18]. Dr. Ramgopal Sharma, Dr, Taru Tiwari, Chhattisgarh ka Prashasan Evam Swatantra Sangram Andolan (1854-1947), P.43.

[19]. Ibid., P.66. 